\title{
Є.В. Шевчук, А.Ю. Лиманська
}

\section{Активність автоімунного процесу у вагітних із системним червоним вовчаком}

\author{
ДУ «Інститут педіатрії, акушерства і гінекології імені академіка О.М. Лук'янової НАМН України», м. Київ
}

Ukrainian Journal of Perinatology and Pediatrics. 2019. 3(79): 10-14; doi 10.15574/PP.2019.79.10

For citation: Limanska Alu, Shevchuk ED. (2019). Autoimmune Activity in Pregnant Women with Systemic Lupus Erythematosus. Ukrainian Journal of Perinatology and Pediatrics. 3(79): 10-14. doi 10.15574/PP.2019.79.10

Останніми роками кількість автоімунних захворювань суттєво зростає у світі, зокрема, в осіб репродуктивного віку. Вагітність є фактором розвитку або загострення автоімунних захворювань.

Мета - визначити спектр антитіл у вагітних із системним червоним вовчаком (СЧВ) залежно від ураження органів-мішеней для встановлення активності автоімунного процесу, а в подальшому — для призначення адекватного лікування і визначення прогнозу.

Пацієнти та методи. Нами обстежено 96 вагітних із СЧВ, серед яких було 34 жінки з антифосфоліпідним синдромом (АФС) і 62 жінки без АФС. У групі жінок із СЧВ без АФС I ступінь активності відмічався у 48 вагітних, II ступінь - у 14 жінок. У жінок із СЧВ у поєднанні АФС I ступінь активності спостерігався у 22 вагітних, II ступінь - у 12 жінок. Спектр автоімунних антитіл визначено за стандартною методикою в лабораторії з європейською сертифікацією.

Результати та висновки. У 75\% вагітних із СЧВ ІІ ступеня активності та майже у $60 \%$ вагітних із СЧВ І ступеня активності виявляються антитіла до двоспіральної ДНК (dsDNA), які є лабораторним маркером СЧВ і майже не зустрічаються при інших захворюваннях сполучної тканини.

Ураження органів-мішеней спостерігаються у всіх досліджуваних вагітних, але значно більший відсоток кардиту та пневмоніту реєструється в жінок із СЧВ ІІ ступеня активності.

За нашими даними, існує прямий кореляційний зв'язок між наявністю позитивних антитіл до двоспіральної ДHК (dsDNA) у високих титрах і люпуснесритом у вагітних із СЧВ ІІ ступеня активності.

У групі вагітних із СЧВ і АФС за допомогою кількісного методу оцінки ризику тромбоемболічних ускладнень виявлено вкрай високий ризик виникнення тромбозів, що обумовлює необхідність ефективної тромбопрофілактики.

Дослідження виконано згідно з принципами Гельсінської Декларації. Протокол дослідження ухвалено Локальним етичним комітетом зазначеної у роботі установи. На проведення досліджень отримано поінформовану згоду жінок.

Автори заявляють про відсутність конфолікту інтересів.

Ключові слова: системний червоний вовчак, антифоссоліпідний синдром, вагітні, автоімунні антитіла.

\section{Autoimmune Activity in Pregnant Women with Systemic Lupus Erythematosus}

A.Iu. Limanska, E.D. Shevchuk

SI «Institute of Pediatrics, Obstetrics and Gynecology named of academician O.M. Lukyanova NAMS of Ukraine», Kyiv

In recent years, the number of autoimmune diseases has been increasing significantly worldwide, in particular, in people of reproductive age. Pregnancy is a factor in the development or exacerbation of autoimmune diseases.

Purpose is to determine the spectrum of antibodies in pregnant women with systemic lupus erythematosus (SLE) depending on the damage of target organs to establish the activity of the autoimmune process, and in the future, to prescribe an adequate treatment, and to determine the prognosis.

Patients and methods. We examined 96 pregnant women with SLE, among whom there were 34 women with antiphospholipid syndrome (APS) and 62 women without APS. In the group of women with SLE without APS, the I degree of activity was observed in 48 pregnant women, II degree - in 14 women. In women with SLE in combination with APS I degree of activity was observed in 22 pregnant women, II degree - in 12 women. The spectrum of autoimmune antibodies was determined according to standard methods in a laboratory with European certification.

Results and conclusions. In $75 \%$ of pregnant women with SLE II degree of activity, and in almost $60 \%$ of pregnant women with SLE I degree of activity, antibodies to double-stranded DNA (dsDNA) were detected, which are a laboratory marker of SLE and are almost never found in other connective tissue diseases.

Target organ lesions are observed in all pregnant women under study, however, a significantly higher percentage of carditis and pneumonitis is recorded in women with SLE II degree of activity.

According to our data, there is a direct correlation between the presence of positive antibodies to double-stranded DNA (dsDNA) in high titers and lupus nephritis in pregnant women with SLE II degree of activity.

In the group of pregnant women with SLE and APS, using a quantitative method for assessing the risk of thromboembolic complications, an extremely high risk of thrombosis was identified, which necessitates effective thromboprophylaxis.

Key words: systemic lupus erythematosus, antiphospholipid syndrome, pregnant women, autoimmune antibodies.

\section{Активность аутоиммунного процесса у беременных с системной красной волчанкой \\ Е.В. Шевчук, А.Ю. Лиманская}

ГУ «Институт педиатрии, акушерства и гинекологии имени академика Е.М. Лукьяновой НАМН Украины», г. Киев

В последние годы количество аутоиммунных заболеваний существенно возрастает в мире, в частности, у лиц репродуктивного возраста. Беременность является фрактором развития или обострения аутоиммунных заболеваний

Цель - определить спектр антител у беременных с системной красной волчанкой (СКВ) в зависимости от поражения органов-мишеней для установления активности аутоиммунного процесса, а в дальнейшем - для назначения адекватного лечения и определения прогноза.

Пациенты и методы. Нами обследованы 96 беременных с СКВ, среди которых было 34 женщины с антифоссолипидным синдромом (АФС) и 62 женщины без АФС. В группе женщин с СКВ без АФС І степень активности отмечалась у 48 беременных, II степень - у 14 женщин. У женщин с СКВ в сочетании с АФС I степень активности наблюдалась у 22 беременных, II степень - у 12 женщин. Спектр аутоиммунных антител определен по стандартной методике в лаборатории с европейской сертификацией

Результаты и выводы. У 75\% беременных с СКВ ІІ степени активности и почти у $60 \%$ беременных с СКВ I степени активности обнаружены антитела к двухспиральной ДНK (dsDNA), которые являются лабораторным маркером СКВ и почти не встречаются при других заболеваниях соединительной ткани. 
Поражения органов-мишеней наблюдаются во всех исследуемых беременных, но более высокий процент кардита и пневмонита регистрируется у женщин с СКВ II степени активности.

По нашим данным, существует прямая корреляционная связь между наличием положительных антител к двуспиральной ДНK (dsDNA) в высоких титрах и люпус-нефритом у беременных с CKВ II степени активности.

В группе беременных с СКВ и АФС с помощью количественного метода оценки риска тромбоэмболических осложнений выявлен крайне высокий риск возникновения тромбозов, что обусловливает необходимость эффективной тромбопросилактики.

Исследование выполнено в соответствии с принципами Хельсинской Декларации. Протокол исследования утвержден Локальным этическим комитетом указанного в работе учреждения. На проведение исследований получено информированное согласие женщин.

Авторы заявляют об отсутствии конфликта интересов.

Ключевые слова: системная красная волчанка, антифоссолипидный синдром, беременные, аутоиммунные антитела

$\mathrm{O}$ станніми роками кількість автоімунних захворювань суттєво зростає у світі, зокрема, в осіб репродуктивного віку. Вагітність є фактором розвитку або загострення автоімунних захворювань. За даними літератури, навіть за умови стабільної клініко-лабораторної ремісії в прегравідарному періоді, 3 настанням вагітності загострення розвивається у $26 \%$ випадків, а за наявності активної фази системного червоного вовчака (СЧВ) до вагітності, ступінь активності підвищується у 37\% випадків. За даними провідних клінік світу, у післяпологовому періоді спостерігається до 51\% загострень СЧВ $[2,4]$.

У вагітних із цією патологією зростає частота загрози переривання вагітності, мимовільних викиднів і формування первинної плацентарної дисфункції, звичного невиношування, гіпотрофiї плода та новонародженого, перинатальної летальності, а також аномалій пологової діяльності й післяпологових ускладнень $[1,4]$.

Системний червоний вовчак є автоімунною патологією, тому доцільно визначати автоімунні антитіла, по-перше, для диференційної діагностики, а по-друге, для встановлення активності процесу.

В усіх пацієнтів із СЧВ для встановлення діагнозу рекомендують визначати антинуклеарні антитіла (АНА). Позитивний тест на АНА входить до класифікаційних критеріїв СЧВ, виявляється у 95\% пацієнтів, але не є специфічним для СЧВ, нерідко буває позитивним у пацієнтів з іншими ревматичними і неревматичними захворюваннями.

Спектр АНА включає в себе велику групу автоантитіл до ДНК, нуклеопротеїдів, гістонів, ядерних рибонуклеопротеїдів та інших компонентів ядра. Тест спрямований на виявлення різних антитіл до компонентів ядра і цитоплазми, які вперше виявлені при СЧВ. У скринінгових тестах для визначення сумарних АНА зазвичай використовують набір таких антигенів, що є основними маркерами автоімунних за- хворювань сполучної тканини: SS-A (Ro), SS-B (La), Scl-70, Sm, RNP/Sm, J01, центромере B.

До класифікаційних критеріїв СЧВ входить визначення антитіл до RNP/Sm-антигену. Антитіла до Sm-антигену виявляються у 20-50\% пацієнтів і складаються з U1 рибонуклеопротеїдів: U1-68, U1-A, U1-C, U5, U6; а також із Sm-поліпептидів: $\mathrm{SmA} \mid$, SmB $\mid$ B, SmD, SmE, SmF, SmG.

B усіх пацієнтів у разі підозри на СЧВ рекомендують визначати антитіла до РНКполімерази (Ro-антигену, SS-A (Ro) і протеїну, що входить до складу РНК (La-антигену SS-B (La)), для диференційної діагностики 3 лімфопенією, тромбоцитопенією, фотодерматитом, легеневим фіброзом, синдромом Шегрена. Антитіла до SS-A (Ro) при СЧВ виявляються у 30\% випадків. Вважають, що такі антитіла, виявлені в крові у вагітних, є показником ризику збільшення виникнення неонатального вовчакоподібного синдрому в новонародженого (неонатальний люпус-синдром). Ці антитіла матері проходять через плаценту і спричиняють ураження плода, що призводять до гемолітичної анемії і тромбоцитопенії. До тяжких наслідків відносять ураження провідної системи серця дитини (аж до постійної кардіостимуляції). Відзначено, що в жінок, у яких під час вагітності виявлено значний титр цих антитіл, без явних клінічних ознак, у подальшому розвивається будь-яке автоімунне захворювання, включаючи СЧВ. Антитіла до La-антигену SS-B (La) виникають у $15 \%$ пацієнтів із СЧВ $[3,5]$.

Для СЧВ характерна Кумбс-позитивна гемолітична анемія. Позитивна реакція Кумбca, яка також рекомендована в схемах діагностики СЧВ, виявляється у 30-40\% пацієнтів, але лише у 10-15\% розвивається гемоліз. Позитивна реакція Кумбса за відсутності гемолітичної анемії є ознакою СЧВ, і стійка хибно позитивна реакція Вассермана при лабораторно підтвердженій відсутності сифілісу входить до класифікаційних критеріїв СЧВ. 
Спектр автоімунних антитіл у вагітних із системним червоним вовчаком

з урахуванням ураження органів-мішеней, абс. (\%)

\begin{tabular}{|c|c|c|c|c|}
\hline Показник & $\begin{array}{c}\text { СЧВ І ступеня } \\
\text { активності без } \\
\text { АФС }\end{array}$ & $\begin{array}{c}\text { СЧВ II ступеня } \\
\text { активності без } \\
\text { АФС }\end{array}$ & $\begin{array}{c}\text { СЧВ І ступеня } \\
\text { активності } \\
\text { з АФС }\end{array}$ & $\begin{array}{c}\text { СЧВ ІІ ступеня } \\
\text { активності } \\
\text { з АФС }\end{array}$ \\
\hline АНА (антинуклеарні антитіла) сумарні & $33(68,75)$ & $14(100)$ & $14(63,6)$ & $12(100)$ \\
\hline Антитіла до RNP/Sm-антигену & $6(12,5)$ & - & - & - \\
\hline Антитіла до Ro-антигену SS-A (Ro) & - & $2(14,3)$ & - & $1(8,3)$ \\
\hline Антитіла до La-антигену SS-B (La) & - & $2(14,3)$ & $1(4,5)$ & $4(33,3)$ \\
\hline Антитіла до двоспіральної ДНК (dsDNA) & $27(56,3)$ & $14(85,7)$ & $13(59,1)$ & $9(75,0)$ \\
\hline Люпус-нефрит & - & $9(64,3)$ & $2(9,0)$ & $8(66,6)$ \\
\hline Кардит & $8(16,6)$ & $8(57,1)$ & $8(36,4)$ & $7(58,3)$ \\
\hline Плеврит, пневмоніт & $4(8,3)$ & $3(21,4)$ & $7(31,8)$ & $5(41,6)$ \\
\hline
\end{tabular}

Встановлення антинейтрофільних цитоплазматичних антитіл SLc70 і антитіл до рибонуклепротеїну в жінок із СЧВ рекомендують для оцінки прогнозу захворювання і визначення тактики лікування.

Аналіз на антитіла до двоспіральної ДНК високочутливий і високоспецифічний маркер для діагностики СЧВ, тобто позитивний результат підтверджує діагноз, а ї рівень зазвичай корелює з активністю вовчакового нефриту. Антитіла до dsDNA виявляють у $70-80 \%$ хворих. Але недостатня чутливість дослідження вимагає обережності в трактуванні результату аналізу (тобто негативний результат не виключає діагнозу СЧВ).

Вовчаковий антикоагулянт виявляється у 20\% пацієнтів із СЧВ. У таких пацієнтів частіше розвиваються тромботичні ускладнення, такі як венозні тромбози (часто), артеріальні тромбози в ділянці нижніх кінцівок, мозкових вен, у судинах легень (рідше). У пацієнтів з артеріальним тромбозом розвивається васкуліт.

Mema дослідження - визначити спектр антитіл у вагітних із СЧВ залежно від ураження органів-мішеней для встановлення активності автоімунного процесу, а в подальшому для призначення адекватного лікування і визначення прогнозу.

\section{Матеріали та методи дослідження}

Нами обстежено 96 вагітних із СЧВ, серед яких було 34 жінки з антифосфоліпідним синдромом (АФС) і 62 жінки без АФС. У групі із СЧВ без АФС І ступінь активності відмічався у 48 вагітних, II ступінь - у 14 жінок. У групі із СЧВ у поєднанні АФС І ступінь активності спостерігався у 22 вагітних, II ступінь у 12 жінок. Спектр автоімунних антитіл визначено за стандартною методикою в лабораторії з європейською сертифікацією.
Дослідження виконано згідно з принципами Гельсінської Декларації. Протокол дослідження ухвалено Локальним етичним комітетом зазначеної в роботі установи. На проведення досліджень отримано поінформовану згоду жінок.

\section{Результати дослідження та їх обговорення}

За результатами наших досліджень, у жінок із СЧВ ІІ ступеня активності без АФС люпуснефрит відмічався у 9 вагітних, а в жінок iз СЧВ II ступеня в поєднанні 3 АФС у 8 жінок. Нами визначено спектр автоімунних антитіл у вагітних з урахуванням органівмішеней, зокрема нирок, серця, легень.

За даними таблиці 1 , у вагітних із СЧВ ІІ ступеня активності в обох групах спостерігалися сумарні АНА в 100\% випадків. 3 великою частотою сумарні АНА діагностувалися в групі вагітних із СЧВ I ступеня активності без АФС і в поєднанні з АФС (68,75\% та 63,6\% відповідно до кількості хворих у кожній групі).

Антитіла до RNP/Sm-антигену діагностувалися лише в $6(12,5 \%)$ вагітних із СЧВ І ступеня активності без АФС. Слід зазначити, що ці антитіла частіше за все (у 90\% випадків) визначалися за умови змішаних захворювань сполучної тканини і рідше - при ізольованому СЧВ. У нашому дослідженні 4 вагітні мали супутній діагноз - ревматоїдний артрит, а 2 жінки - дерматоміозит.

За даними таблиці 1, антитіла до Rо-антигену SS-A (Ro) спостерігалися у 2 (14,3\%) вагітних із СЧВ II ступеня активності без АФС та в 1 (8,3\%) жінки із СЧВ у поєднанні з АФС. Слід відмітити, що поява цих антитіл є маркером виникнення неонатального вовчакоподібного синдрому в новонародженого (неонатальний люпус-синдром), гемолітичної анемії, тромбоцитопенії, тяжких уражень провідної 
Кореляційний зв'язок наявності антитіл до двоспіральної ДНК (dsDNA)

і люпус-нефриту у вагітних із системним червоним вовчаком

\begin{tabular}{|l|c|c|c|c|}
\hline \multirow{2}{*}{\multicolumn{1}{|c|}{ Група вагітних }} & \multicolumn{4}{|c|}{ Група вагітних } \\
\cline { 2 - 5 } & \multicolumn{2}{c|}{$\begin{array}{c}\text { СЧВ ІІ ступеня активності } \\
\text { + люпус-нефрит }\end{array}$} & $\begin{array}{c}\text { СЧВ II ступеня активності і АФС } \\
\text { + люпус-нефрит }\end{array}$ \\
\cline { 2 - 5 } & r- & P & r- & P \\
\hline $\begin{array}{l}\text { Позитивні антитіла до двоспіральної } \\
\text { ДНК (dsDNA) у високих титрах }\end{array}$ & 0,56 & $<0,05$ & 0,61 & $<0,05$ \\
\hline
\end{tabular}

системи серця дитини. У наших дослідженнях y вагітних із наявністю антитіл до Rо-антигену SS-A (Ro) діагностувався ще супутній синдром Шегрена і вагітність закінчилася завмерлим плодом у терміні 18-21 тиждень вагітності.

Антитіла до La-антигену SS-B (La), за даними літератури, спостерігалися при ізольованій СЧВ у 15\% випадків, а при поєднанні із синдромом Шегрена - майже у 70\%. Так, за даними таблиці 1, антитіла до La-антигену SS-B (La) діагностувалися здебільшого у вагітних із СЧВ II ступеня активності за наявності АФС і синдрому Шегрена в 33,3\% випадків.

Антитіла до двоспіральної ДНК (dsDNA), які є лабораторним маркером СЧВ і майже не зустрічаються при інших захворюваннях сполучної тканини, в наших дослідженнях діагностувались у понад 75\% вагітних із СЧВ II ступеня активності та майже у 60\% вагітних із СЧВ І ступеня активності.

Ураження органів-мішеней спостерігалися у всіх досліджуваних вагітних, але значно вищий показник кардиту та пневмоніту відмічався в жінок із СЧВ ІІ ступеня активності (табл. 1).

За нашими даними, існує прямий кореляційний зв'язок між наявністю позитивних антитіл до двоспіральної ДНК (dsDNA) у високих титрах і люпус-нефритом у вагітних із СЧВ II ступеня активності (табл. 2).

Слід зазначити, що таке ускладнення, як люпус-нефрит, мали 2 (9,0\%) жінки із СЧВ І ступеня активності в поєднанні з АФС, 9 (64,3\%) вагітних із СЧВ II ступеня активності без АФС, 8 (66,6\%) жінок із СЧВ II ступеня активності в поєднанні з АФС. Враховуючи відсутність прогностичних критеріїв ступеня ураження нирок у хворих із люпус-нефритом та для верифікації діагнозу і призначення адекватної імуносупресивної терапії, відповідно до міжнародних рекомендацій KDIGO, необхідним є проведення біопсії нирок для морфологічного дослідження і визначення класу вовчакового нефриту.

Біопсія нирок проводилася 2 вагітним із СЧВ II ступеня активності (за результатами морфологічного дослідження виявлявся вовча- ковий нефрит III класу - вогнищевий проліферативний $<50 \%$ ураження ниркових клубочків) i 3 вагітним із СЧВ II ступеня активності в поєднанні з АФС (із них у 2 жінок діагностувався V клас люпус-нефриту (мембранозний), в 1 вагітної - IV клас нефриту (дифузний проліферативний $>50 \%$ ураження ниркових клубочків). Саме у 3 жінок із наявністю антитіл до Ro-антигену SS-A (Ro), антитіл до двоспіральної ДНК (dsDNA) i вовчаковим нефритом вагітність закінчилася завмерлим плодом у терміні 19-21 тиждень вагітності.

Серед обстежених нами вагітних із СЧВ супутній АФС був у 34 жінок.

Антифосфоліпідні антитіла (до кардіоліпіну, до 2-глікопротеїну I, а також вовчаковий антикоагулянт) виявлялися у $50-60 \%$ із СЧВ $\mathrm{i}$, як і хибно позитивна реакція Вассермана, є серологічними маркерами вторинного АФС.

За критеріями Sapporo, АФС діагностувався у 22 жінок із СЧВ І ступеня активності і 12 жінок із СЧВ ІІ ступеня активності.

В основі АФС лежить незапальна тромботична васкулопатія, яка виникає в судинах

Таблиия 3

Розрахунок ризику тромбозів під час вагітності за шкалою Schoenbeck D.

\begin{tabular}{|c|c|}
\hline Фактор ризику & Бал \\
\hline Вік >35 років & 0,5 \\
\hline Вага >120 кг & 0,5 \\
\hline $\begin{array}{l}\text { Епізод венозної тромбоемболії (ВTE) } \\
\text { у родичів I та II ступеня }\end{array}$ & 0,5 \\
\hline $\begin{array}{l}\text { Передчасний неакушерський } \\
\text { спровокований епізод ВТЕ }\end{array}$ & 1,0 \\
\hline Передчасний акушерський спровокований епізод ВТЕ & 2,0 \\
\hline $\begin{array}{l}\text { Передчасний епізод ВТЕ на тлі використання } \\
\text { гормональних контрацептивів }\end{array}$ & 2,0 \\
\hline Дефріцит антитромбіну III & 3,0 \\
\hline Десіцит протеїну C & 1,5 \\
\hline Десріцит протеїну S & 1,0 \\
\hline Мутація фрактора V Лейдена & 1,0 \\
\hline Мутація протромбіну (G20210A) & 1,0 \\
\hline Антифросфоліпідні антитіла & 1,0 \\
\hline
\end{tabular}


Кількість балів за шкалою Schoenbeck D. у вагітних із системним червоним вовчаком

Таблиия 4

\begin{tabular}{|l|c|c|c|c|}
\hline $\begin{array}{c}\text { Сумарний результат } \\
\text { за шкалою }\end{array}$ & $\begin{array}{c}\text { СЧВ I ступеня } \\
\text { активності без АФС }\end{array}$ & $\begin{array}{c}\text { СЧВ ІІ ступеня } \\
\text { активності без АФС }\end{array}$ & $\begin{array}{c}\text { СЧВ І ступеня } \\
\text { активності з АФС }\end{array}$ & $\begin{array}{c}\text { СЧВ ІІ ступеня } \\
\text { активності з АФС }\end{array}$ \\
\hline $1-1,5$ балу & $14(29,2)$ & $4(28,4)$ & $10(45,5)^{\star}$ & $6(50,0)^{*}$ \\
\hline $2,0-2,5$ балу & $4(8,3)$ & $2(14,3)$ & $5(22,7)^{\star}$ & $3(25)^{\star}$ \\
\hline$>3,0$ балу & $4(8,3)$ & $1(7,1)$ & $3(13,6)^{\star}$ & $2(16,6)^{\star}$ \\
\hline
\end{tabular}

Примітка: * - p<0,05, достовірність різниці порівняно між показниками в групах СЧВ з АФС та СЧВ без АФС.

будь-якого калібру і локалізації, тому особливу увагу необхідно приділяти тромбопрофілактиці в цій групі пацієнток. В усіх вагітних із СЧВ у поєднанні з АФС слід визначати ризик тромбозу і проводити адекватну тромбопрофілактику, що визначається за шкалою Schoenbeck D., 2011 (табл. 3).

Обстеження ризиків виникнення тромбозів у вагітних із СЧВ та АФС наведено в таблиці 4.

Слід зазначити, що не виявлено суттєвої різниці в групах вагітних із СЧВ у поєднанні з АФС за кількістю балів. Так, майже половина вагітних в обох групах мали 1-1,5 балу за шкалою ризику виникнення тромбозів, зокрема, 45,5\% жінок із СЧВ I ступеня в поєднанні 3 АФС і 50\% вагітних із СЧВ II ступеня активності в поєднанні з АФС.

Слід зазначити, що близько 30\% вагітних iз СЧВ I та II ступеня активності у поєднанні 3 АФС мали ризик виникнення тромбозів $\geq 3$ балів і потребували призначення НМГ протягом усієї вагітності і 6 тижнів після вагітності.

Під час порівняння із вагітними з СЧВ без АФС виявлено, що 29,2\% жінок із СЧВ І ступеня та 28,4\% вагітних із СЧВ II ступеня мали ризик виникнення тромбозів в 1-1,5 балу, що обумовило необхідність призначення НМГ протягом 6 тижнів після пологів. Показники у 2-2,5 балу та 3 балу були суттєво нижчими в групі вагітних із СЧВ без АФС.
Суттєво високі показники ризику виникнення тромбозів спостерігалися в групі вагітних із СЧВ у поєднанні з АФС, що обумовило необхідність тромбопрофілактики.

\section{Висновки}

У 75\% вагітних із СЧВ ІІ ступеня активності та майже у 60\% вагітних із СЧВ І ступеня активності виявляються антитіла до двоспіральної ДНК (dsDNA), які є лабораторним маркером СЧВ і майже не зустрічаються при інших захворюваннях сполучної тканини.

Ураження органів-мішеней спостерігаються у всіх досліджуваних вагітних, але значно більший відсоток кардиту та пневмоніту реєструється в жінок із СЧВ II ступеня активності.

За нашими даними, існує прямий кореляційний зв'язок між наявністю позитивних антитіл до двоспіральної ДНК (dsDNA) у високих титрах і люпус-нефритом у вагітних із СЧВ II ступеня активності.

У групі вагітних із СЧВ і АФС за допомогою кількісного методу оцінки ризику тромбоемболічних ускладнень виявлено вкрай високий ризик виникнення тромбозів, що обумовлює необхідність ефективної тромбопрофілактики.

Автори заявляють про відсутність конфлікmу інтересів.

\section{References/Література}

1. Davydova Yu, Shevchuk E, Limanskaya A, Garmish E, Ogorodnyk AA (2016). The features of pregnancy and delivery in pregnant women with systemic lupus erythematosus and antiphospholipid syndrome. Perinatologiya i pediatriya. 2016. 2(66): 9-13. [Давыдова ЮВ, Шевчук EB, Лиманская АЮ, Гармиш ЕА, Огородник АА. (2016). Особенности течения беременности и родов у беременных с системной красной волчанкой и антифосфолипидным синдромом. Перинатология и педиатрия. 2(66): 9-13]. doi 10.15574/PP.2016.66.9

2. Carvalheiras G, Vita P, Marta S, Trovao R, Farinha F, Braga J, Rocha G, Almeida I, Marinho A, Mendonca T et al. (2010). Pregnancy and systemic lupus erythematosus: review of clinical features and outcome of 51 preg-

nancies at a single institution. Clin Rev Allergy Immunol. 38 (2-3): 302-306.

3. Hutter D, Silverman ED, Jaeggi ET. (2010). The benefits of transplacental treatment of isolated congenital complete heart block associated with maternal anti-Ro/SSA antibodies: a review. Scand J Immunol. 72 (3): 235-241.

4. Kwok LW, Tam LS, Zhu T, Leung YY, Li E. (2011). Predictors of maternal and fetal outcomes in pregnancies of patients with systemic lupus erythematosus. Lupus. 20 (8): 829-836.

5. Lateef A, Petri M. (2012). Management of pregnancy in systemic lupus erythematosus. Nat Rev Rheumatol. 8 (12): 710-718.

Відомості про авторів:

Лиманська Аліса Юріївна - вед.н.с. відділення акушерських проблем екстрагенітальної патології ДУ «ІПАГ імені академіка О.М. Лук'янової НАМН України».

Адреса: м. Київ, вул. П. Майбороди, 8. https://orcid.org/0000-0003-0639-7005

К Київ, вул. П. Майбороди, 8.

Стаття надійшла до редакції 28.04.2019 р.; прийнята до друку 15.09.2019 р. 